\title{
Analisis SWOT Potensi dan Daya Tarik Wisata Osing Kemiren Dalam Rangka Pengembangan Desa Adat Osing Kemiren Kecamatan Glagah Kabupaten Banyuwangi Tahun 2021
}

\author{
Luluk Lestari ${ }^{* 1}$ Lulup Endah Tripalupi² \\ Program Studi Pendidikan Ekonomi \\ Universitas Pendidikan Ganesha \\ Singaraja, Indonesia
}

e-mail: luluklestari22@gmail.com¹,tripalupilulup@gmail.com²

Pengutipan:

Lestari,L.,

Tripalupi,E,L.

\&Suwena, K, R

(2021). Analisis

SWOT Potensi

dan Daya Tarik

Wisata Osing

Kemiren Dalam

Rangka

Pengembangan

Desa Adat Osing

Kemiren

Kecamatan

Glagah

Kabupaten

Banyuangi Tahun

2021. Jurnal

Pendidikan

Ekonomi

Undiksha,

13(2),328-339

http://dx.doi.org/1

$0.23887 /$ iipe.v13i

$\underline{2.35511}$

\begin{abstract}
Abstrak
Riwayat Artikel Tanggal diajukan: 15 Juni 2021

Tanggal diterima : 22 November 2021

Tanggal dipublikasikan: 15 Desember 2021

Penelitian ini merupakan penelitian deskriptif kualitatif, yang bertujuan untuk menganalisis bagaimana pengembangan wisata di Desa Adat Osing Kemiren dengan menggunakan analisis SWOT (Strength, Weakness, Opportunity dan Treats). Penelitian ini menunjukkan bahwa kekuatan yang dimiliki obyek wisata Desa Adat Osing Kemiren yaitu, mempunyai potensi panorama desa yang masih asri, tersedianya event-event yang menarik, kebersihan, sarana dan prasarana yang baik dan keramahan masyarakat. Kelemahan yang dimiliki Desa Adat Osing Kemiren yaitu, kurang tersedianya air bersih dalam toilet, kurangnya sistem keamanan dan pengawasan, dan SDM yang masih rendah. Peluang yang dimiliki Desa Adat Osing Kemiren yaitu, kelestarian budaya masyarakat sekitar, membuka lapangan pekerjaan, kebijakan pemerintah, ketersediaan informasi obyek wisata di internet dan media sosial. Ancaman yang dimiliki Desa Adat Osing Kemiren yaitu, banyaknya pesaing dan berkembangnya sarana dan fasilitas wisata pesaing. Dari diagram SWOT dapat terlihat hasil penelitian menunjukkan bahwa titik potong $(2,38: 2,37)$ berada pada diagram I. Sehingga strategi yang tepat untuk diterapkan dalam strategi pengembangan obyek wisata Desa Adat Osing Kemiren adalah mendukung kebijakan (Growth Oriented Strategy).
\end{abstract}

Kata kunci: Pariwisata; Potensi; Daya Tarik; SWOT

\begin{abstract}
This research is a qualitative descriptive study, which is aims to analyze how tourism development in the Osing Kemiren Traditional Village using a SWOT analysis (Strength, Weakness, Opportunity and Treats). This research shows that the strength of the tourism object in the Osing Kemiren Traditional Village has the potential for a panoramic view of the village which is still beautiful, the availability of interesting events, cleanliness, good facilities and infrastructure and community friendliness. The weaknesses of the Osing Kemiren Traditional Village, the lack of clean water available in the toilets, the lack of a security and supervision system, and low human resources. Opportunities for the Osing Kemiren Traditional Village, cultural preservation of the surrounding community, opening jobs, government policies, availability of information on tourism objects on the internet and social media. The threat of the Osing Kemiren Traditional Village, the number of competitors and the development of competitor tourism facilities. From the SWOT diagram, it can be seen that the research results show that the intersection point (2.38:2.37) is in diagram I. So, the right strategy to be applied in the tourism development strategy of the Osing Kemiren Traditional Village is to support the policy (Growth Oriented Strategy).
\end{abstract}

Keywords : Tourism; Potency; Attractiveness; SWOT 


\section{PENDAHULUAN}

Menurut Wijayati, 2019:05, "Analisis SWOT merupakan suatu metode yang membuat perencanaan strategis guna mengevaluasi kekuatan, kelemahan, peluang dan ancaman yang dapat diaplikasikan dalam suatu proyek atau spekulasi bisnis". Menurut Sarbini, 2018:10, "pariwisata adalah pergerakan, bentuknya perjalanan manusia (wisatawan) baik seseorang maupun beberapa orang". Sejalan dengan itu Rosida, 2018:10 menambahkan, bahwa kegiatan pariwisata dapat membuka wawasan dan memberi kenikmatan dengan cara melakukan perjalanan untuk tujuan rekreasi atau berlibur ke suatu tempat tertentu. Dengan pariwisata orang dapat memperoleh sesuatu yang baik, baru dan belum pernah didapat dari lingkungannya. Obyek wisata dapat berupa tempat-tempat untuk sejarah atau lokasi-lokasi alam yang indah dan atraktif.

Pengembangan desa wisata berupaya menyatukan antara daya tarik wisata alam, wisata buatan dan wisata budaya dalam satu kawasan tertentu dengan didukung adanya atraksi, akomodasi dan dilengkapi dengan fasilitas lainnya yang telah dikelola (Tomas, 2017). Dengan dikembangkannya desa wisata akan menambah daya tarik wisata yang lebih beragam sehingga dapat memanfaatkan sumber daya alam dengan baik untuk menarik minat wisatawan sehingga dapat menguntungkan dan menyejahterakan sekitarnya (Nupus, 2019:02).

Salah satu Kabupaten di Jawa Timur yang berkembang pesat wisatanya adalah Kabupaten Banyuwangi. Dimana destinasidestinasi tersebut diantaranya adalah destinasi-destinasi yang dikelola oleh Desa ataupun kelompok masyarakat di Desa setempat. Pariwisata merupakan salah satu potensi unggulan dan basis pertumbuhan ekonomi di Kabupaten Banyuwangi. Seperti yang telah kita ketahui Kabupaten Banyuwangi dalam kurun waktu terakhir ini mengalami perkembangan pariwisata yang sangat meningkat.

Berdasarkan Arsip Dinas Kebudayaan dan Pariwisata Kabupaten Banyuwangi, tentang jumlah kunjungan wisatawan mulai tahun 2013 sampai tahun 2019 yang datang ke Banyuwangi yaitu: jumlah kunjungan wisatawan domestik sejak tahun 2013 hingga tahun 2019 mengalami peningkatan yang signifikan. Pada tahun 2013 wisatawan domestik yang mengunjungi Kabupaten Banyuwangi sejumlah 1.057.952 orang dan di tahun 2019 meningkat menjadi 5.307.054 orang. Tidak hanya wisatawan lokal, keindahan Banyuwangi juga disorot mancanegara. Terbukti dari jumlah kunjungan wisatawan mancanegara di Kabupaten Banyuwangi pada tahun 2013 sebanyak 10.462 orang, meningkat signifikan menjadi 101.622 orang di tahun 2019.

Sebagai salah satu daerah destinasi wisata di Jawa Timur, Kabupaten Banyuwangi memiliki banyak obyek wisata yang menarik untuk dikembangkan seperti wisata alam, wisata sejarah dan budaya atau wisata lainnya. Akan tetapi ada salah satu desa yang berbeda ketika para wisatawan berkunjung ke Kabupaten Banyuwangi, yaitu desa wisata adat suku osing yang terletak di Desa Kemiren Kecamatan Glagah yang berjarak $5 \mathrm{~km}$ dari pusat Pemerintah Kabupaten dan $2 \mathrm{~km}$ dari pusat Pemerintah Kecamatan. Untuk menjaga kelestarian kebudayaan Banyuwangi, pada tahun 1995 Pemerintah Banyuwangi menetapkan Desa Wisata Osing sebagai cagar budaya.

BUMDES yang ada dikelola oleh remaja karang taruna bersama pemerintah desa. Berdasarkan hasil observasi dan wawancara awal dengan bapak Edi yang merupakan Ketua Kelompok Sadar Wisata (POKDARWIS) menjelaskan bahwa adanya penetapan desa tersebut data kunjungan ke Desa Adat Osing Kemiren pada tahun 2019 sebesar 18.000 orang dan sekali mengadakan event bisa mencapai 2000 orang, hanya saja pada tahun 2020 kunjungan wisatawan turun menjadi 2000 orang dikarenakan adanya pandemi Covid19. Dapat dilihat bahwa sebelum terjadi pandemi Covid-19 wisata Osing ini sangat diminati oleh wisatawan.

Dalam mengembangkan berbagai keanekaragaman potensi yang ada didesa wisata Osing Kemiren, ada beberapa hal yang perlu ditingkatkan terkait fasilitas dan infrastruktur yang masih kurang seperti 
masih terbatasnya lahan untuk area parkir di obyek wisata, minimnya kamar mandi atau toilet, tidak tersedianya art shop atau toko souvenir sebagai penunjang industri pariwisata desa dan sumber daya manusia yang masih rendah dalam bidang pariwisata. Peran masyarakat dalam penentuan pengembangan desa wisata adat di Kemiren memerlukan perhatian khusus agar mampu bertahan dengan adanya modernisasi di zaman seperti ini.

\section{METODE}

Penelitian ini menggunakan metode penelitian deskriptif dengan pendekatan kualitatif. Metode penelitian deskriptif mempunyai tujuan untuk membuat deskripsi, gambaran atau lukisan secara sistematis, faktual dan akurat mengenai fakta-fakta, sifat-sifat, serta hubungan antar fenomena yang diselidiki. Menurut Sugiyono, 2017:35, bahwa "metode penelitian deskriptif adalah penelitian yang dilakukan untuk mengetahui keberadaan variabel mandiri, baik satu variabel atau lebih variabel (variabel yang berdiri sendiri) tanpa membuat perbandingan atau mencari hubungan variabel satu sama yang lain". Definsi dan Operasional Penelitian ini yaitu menggunakan Definisi Variabel Penelitian yang meliputi Lingkungan Internal dan Lingkungan Eksternal sedangkan Operasional Penelitian ini seperti tampak pada tabel berikut ini

Tabel 3.1 Operasional Variabel Penelitian

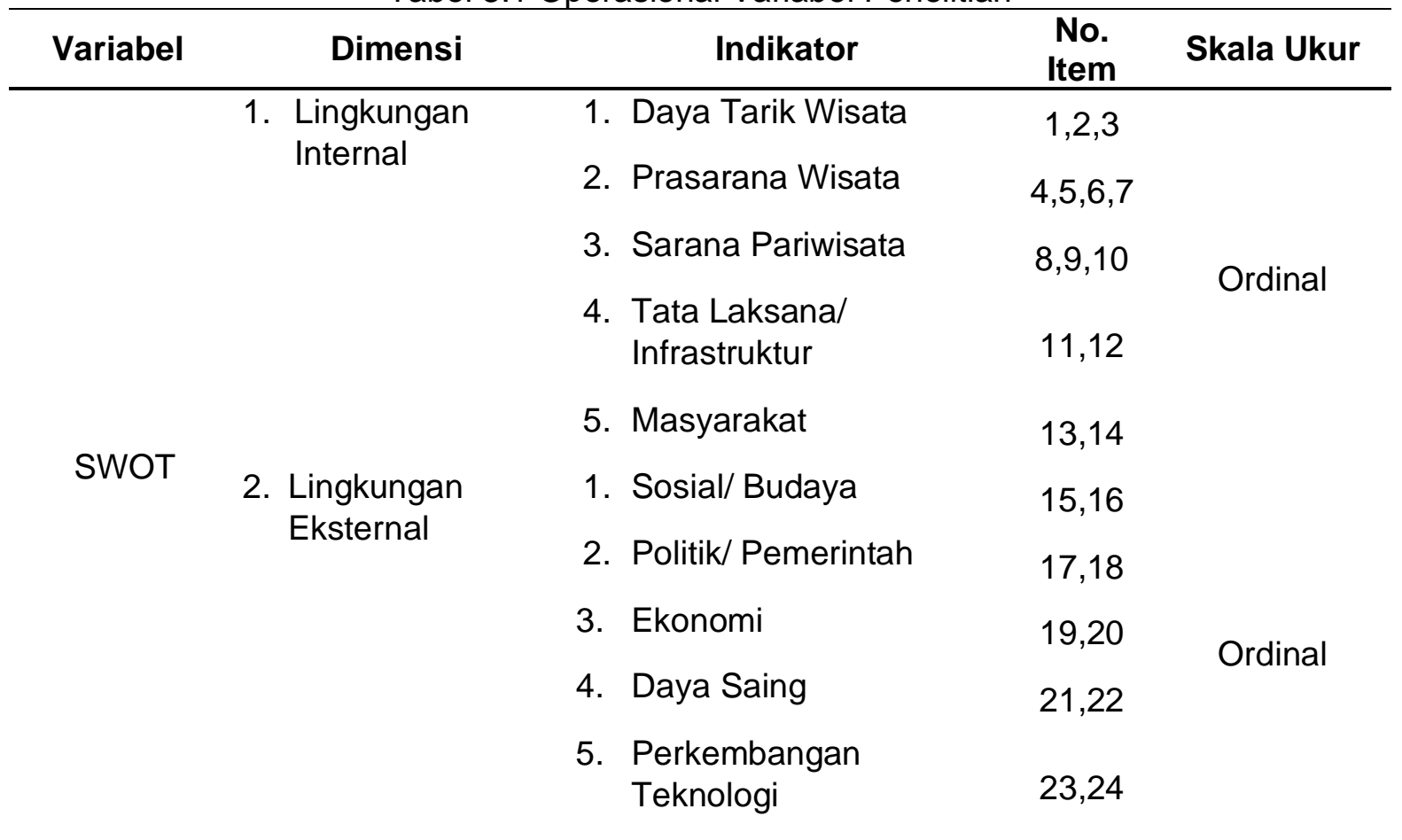

Lokasi Penelitian ini dilaksanakan di Desa Adat Osing Kemiren yang berlokasi di Desa Kemiren Kecamatan Glagah Kabupaten Banyuwangi. Populasi yang diambil dalam penelitian ini adalah semua orang yang melakukan kegiatan wisata di Desa Adat Osing Kemiren pada tahun 2021 yang jumlahnya tidak diketahui dan dapat dikatakan dalam kategori tidak terhingga. Mengingat populasi yang jumlahnya tidak diketahui, dan peneliti tidak mungkin mempelajari semua yang ada pada populasi, misalnya karena keterbatasan dana, tenaga dan waktu, maka peneliti dapat menggunakan sampel yang diambil dari populasi tersebut. Pada penelitian ini peneliti menggunakan teknik pengambilan sampel yaitu teknik incidental sampling. Jumlah sampel yang diambil dalam penelitian ini menggunakan rumus Lemeshow, hal ini dikarenakan jumlah populasi tidak diketahui atau tidak terhingga.

Jenis data yang digunakan dalam penelitian ini adalah data kualitatif dan 
sumber data penelitian ini yaitu data primer dan data sekunder. Dalam penelitian ini metode yang digunakan adalah dengan menggunakan teknik pengumpulan data berupa Kuisioner (Angket). Di dalam teknik ini peneliti mengajukan pertanyaanpertanyaan yang ditujukan kepada responden yang berkaitan dengan analisis SWOT pada obyek wisata Desa Adat Osing Kemiren. Angket ini merupakan instrumen yang utama untuk mengetahui kekuatan, kelemahan, peluang dan ancaman obyek wisata Desa Adat Osing Kemiren. Kuesioner dalam penelitian ini akan diukur dengan menggunakan skala likert. Analisis data yang digunakan dalam penelitian ini adalah analisis deskriptif kualitatif. Dalam penelitian ini menggunakan teknik analisis data SWOT untuk mengidentifikasi kekuatan, kelemahan, peluang dan ancaman dari lingkungan internal dan lingkungan eksternal obyek wisata Desa Adat Osing Kemiren.

\section{HASIL DAN PEMBAHASAN}

Analisis SWOT dalam daerah tujuan wisata, khususnya pada daerah tujuan wisata Desa Adat Osing Kemiren, mempunyai hubungan yang signifikan dalam situasi persaingan dalam pemasaran wisata. Salah satu titik tolak dalam pembahasan ini adalah analisis SWOT. Evaluasi atas analisis SWOT ini mencakup evaluasi atas kekuatan, kelemahan, peluang, dan ancaman dalam suatu daerah tujuan wisata.

Apapun tujuan dan sasaran dari evaluasi analisis SWOT pada daerah tujuan wisata Desa Adat Osing Kemiren adalah sebagai evaluasi dengan menggunakan analisis SWOT, dapat mengetahui bagaimana kekuatan, kelemahan, peluang dan ancaman yang dihadapi oleh daerah tujuan wisata Desa Adat Osing Kemiren.

Mengacu pada tujuan dan sasaran dilakukannya evaluasi atas penerapan analiasis SWOT, maka akan dapat diketahui apa yang menjadi kekuatan dan kelemahan yang dimiliki daerah tujuan wisata Desa Adat Osing Kemiren, dan peluang apa yang mampu mendukung perkembangan wisata dan ancaman yang nantinya akan dihadapi daerah tujuan wisata Desa Adat Osing Kemiren. Analisis internal yang yang menggambarkan kekuatan dan kelemahan obyek wisata Desa Adat Osing Kemiren serta Analisis Analisis eksternal yang menggambarkan peluang dan ancaman obyek wisata Desa Adat Osing Kemiren nampak pada tabel berikut :

Tabel 4.1 Analisis Lingkungan Internal

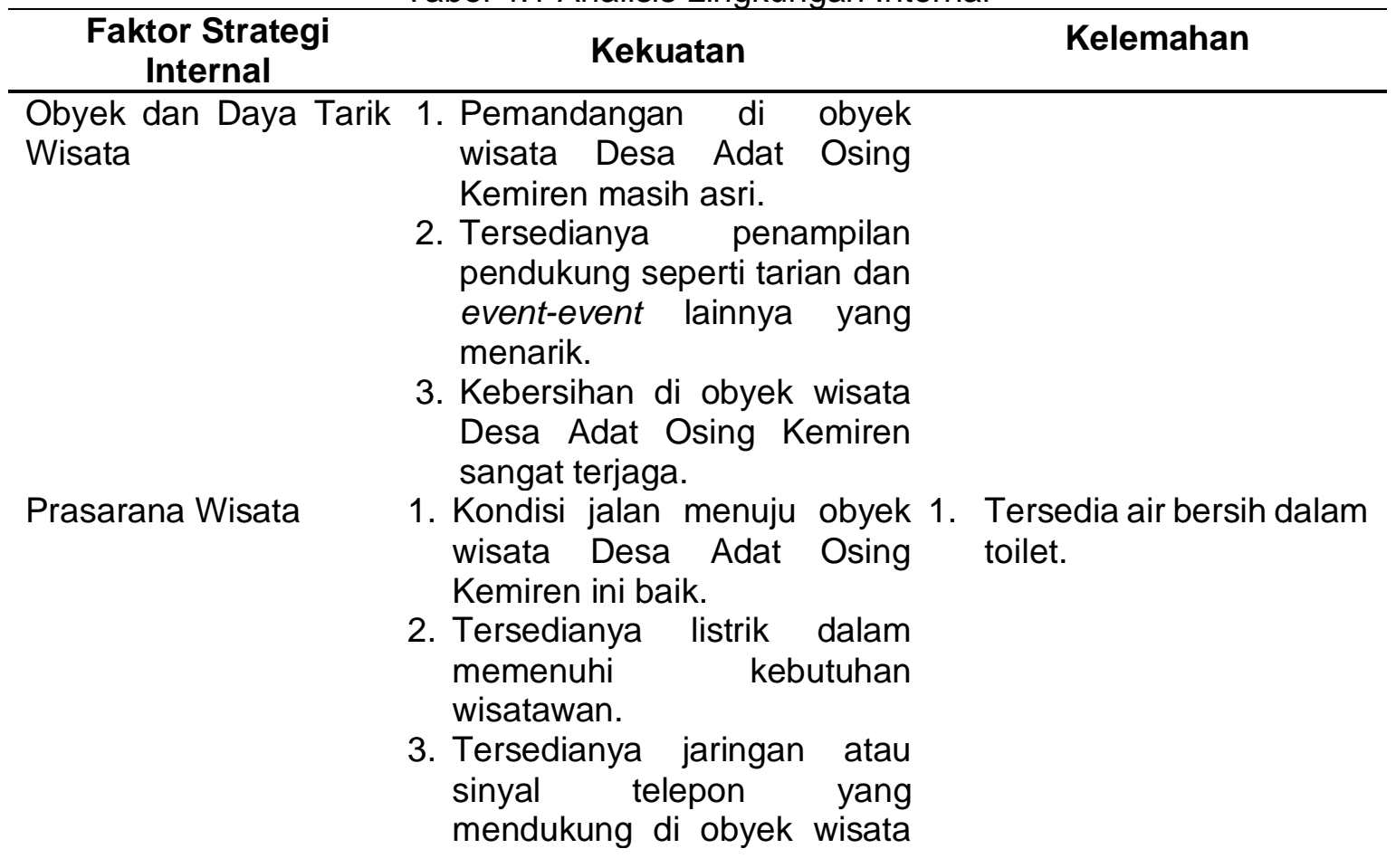




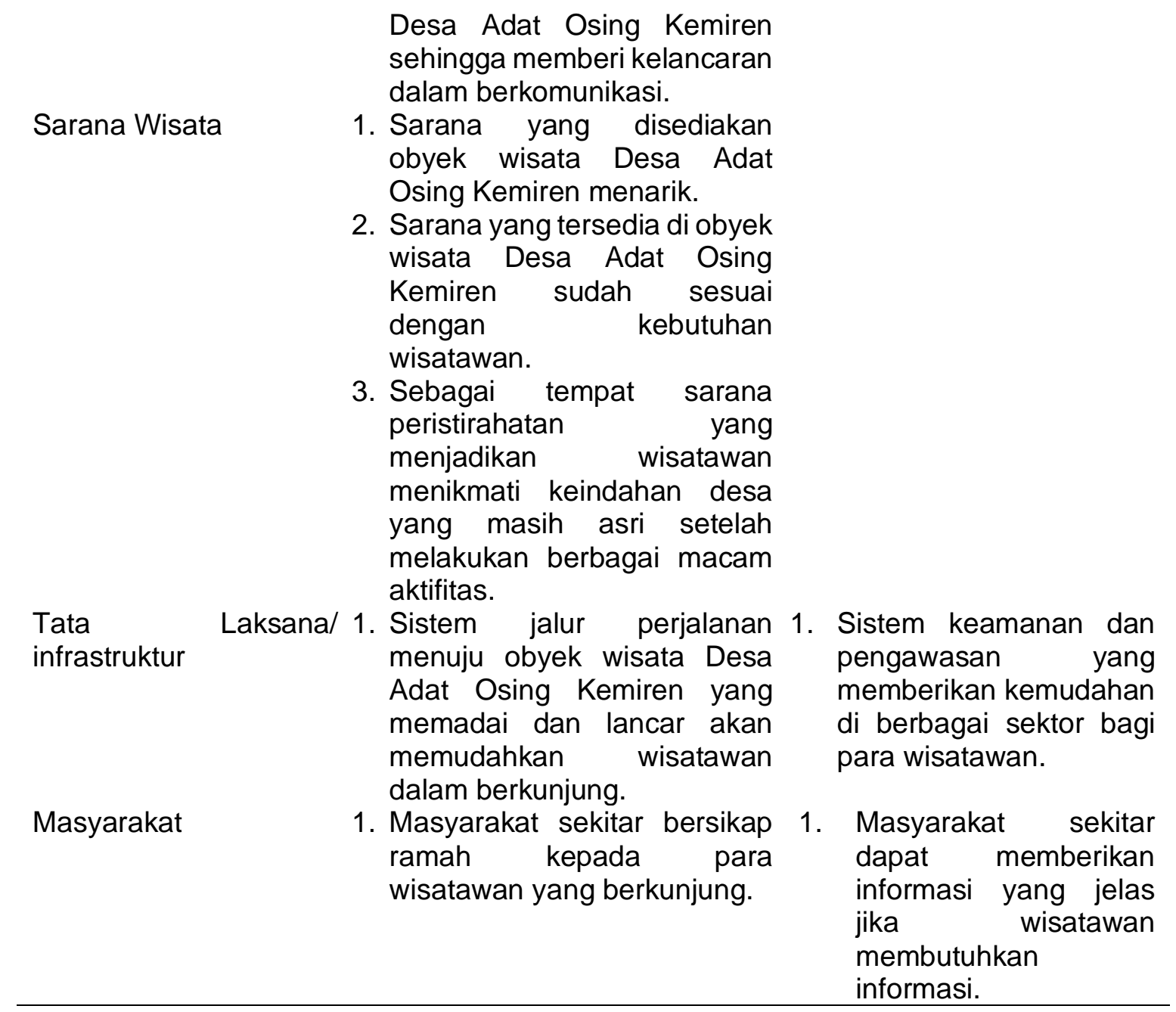

Tabel 4.2 Analisis Lingkungan Eksternal

\begin{tabular}{|c|c|c|}
\hline $\begin{array}{c}\text { Faktor Strategi } \\
\text { Eksternal }\end{array}$ & Peluang & Ancaman \\
\hline Sosial dan Budaya & $\begin{array}{l}\text { 1. Keberadaan obyek wisata } \\
\text { Desa Adat Osing Kemiren } \\
\text { berdampak kepada usaha } \\
\text { yang dikelola oleh } \\
\text { masyarakat sekitar. } \\
\text { 2. Keberadaan obyek wisata } \\
\text { Desa Adat Osing Kemiren } \\
\text { memperkenalkan budaya } \\
\text { Khas Banyuwangi kepada } \\
\text { wisatawan. }\end{array}$ & \\
\hline Politik/ Pemerintah & $\begin{array}{l}\text { 1. Adanya kerja sama antara } \\
\text { perusahaan, pemerintah dan } \\
\text { masyarakat sekitar dalam } \\
\text { mengembangkan obyek } \\
\text { wisata Desa Adat Osing } \\
\text { Kemiren demi tercapainya } \\
\text { pengembangan desa yang } \\
\text { maksimal. }\end{array}$ & \\
\hline
\end{tabular}


Ekonomi

Daya Saing

Perkembangan

Teknologi
2. Tingginya

pemerintah

pengembangan

wisata Desa Adat Osing Kemiren.

1. Adanya obyek wisata Desa Adat Osing Kemiren membantu masyarakat sekitar untuk membuka lapangan pekerjaan.

2. Adanya obyek wisata Desa Adat Osing Kemiren membantu meningkatkan pendapatan masyarakat sekitar.

1.

1. Informasi mengenai obyek wisata Desa Adat Osing Kemiren dapat dengan mudah diakses melalui internet.

2. Ketersediaan informasi mengenai obyek wisata Desa Adat Osing Kemiren dapat dengan mudah, cepat dan tepat untuk didapatkan.
Analisis faktor strategis internal difokuskan pada kondisi yang ada di dalam perusahaan. Setelah mengetahui faktorfaktor strategi internal (kekuatan dan kelemahan), selanjutnya disusun tabel faktor-faktor strategis internal (Internal Strategic Factors Analysis Summary/ IFAS). Faktor-faktor strategis internal (Internal Strategic Factors Analysis Summary/ IFAS) nampak pada Tabel 4.3

Tabel 4.3 Faktor-faktor strategis internal (Internal Strategic Factors Analysis Summary/IFAS)

\section{Faktor-faktor Strategi Internal Kekuatan/ Kelemahan}

\section{Bobot Ranting Skor}

\section{Kekuatan}

$\begin{array}{llll}\text { 1. Pemandangan di obyek wisata Desa Adat Osing Kemiren } & 0,08 & 3,5 & 0,28\end{array}$ masih asri.

2. Tersedianya penampilan pendukung seperti tarian dan event- $\quad 0,08 \quad 3,3 \quad 0,26$ event lainnya yang menarik.

3. Kebersihan di obyek wisata Desa Adat Osing Kemiren sangat $\quad 0,08 \quad 3,3 \quad 0,26$ terjaga.

$0,07 \quad 3,2 \quad 0,22$


4. Kondisi jalan menuju obyek wisata Desa Adat Osing Kemiren ini baik.

5. Tersedianya listrik dalam memenuhi kebutuhan wisatawan.

6. Tersedianya jaringan atau sinyal telepon yang mendukung di obyek wisata Desa Adat Osing Kemiren sehingga memberi kelancaran dalam berkomunikasi.

7. Sarana yang disediakan obyek wisata Desa Adat Osing Kemiren menarik.

$\begin{array}{lll}0,07 & 3,1 & 0,21 \\ 0,07 & 3,2 & 0,22 \\ 0,08 & 3,3 & 0,26 \\ 0,08 & 3,3 & 0,26 \\ 0,08 & 3,3 & 0,26 \\ 0,08 & 3,3 & 0,26 \\ & & \\ 0,08 & 3,3 & 0,26\end{array}$

8. Sarana yang tersedia di obyek wisata Desa Adat Osing Kemiren sudah sesuai dengan kebutuhan wisatawan.

9. Sebagai tempat sarana peristirahatan yang menjadikan wisatawan menikmati keindahan desa yang masih asri setelah melakukan berbagai macam aktifitas.

10. Sistem jalur perjalanan menuju obyek wisata Desa Adat Osing Kemiren yang memadai dan lancar akan memudahkan wisatawan dalam berkunjung.

11. Masyarakat sekitar bersikap ramah kepada para wisatawan yang berkunjung.

Jumlah

\section{Kelemahan}

1. Tersedia air bersih dalam toilet.

$0,05 \quad 2,6 \quad 0,13$

2. Sistem keamanan dan pengawasan yang memberikan kemudahan di berbagai sektor bagi para wisatawan.

$0,05 \quad 2,5 \quad 0,12$

3. Masyarakat sekitar dapat memberikan informasi yang jelas jika wisatawan membutuhkan informasi.

$$
\begin{aligned}
& \text { Ukuran Bobot } \\
& 0,00 \quad \text { : Tidak penting } \\
& 0,05 \quad \text { : Sedikit penting } \\
& 0,10 \quad \text { : Cukup penting } \\
& 0,15 \quad \text { : Penting } \\
& 0,20 \quad \text { : Sangat penting }
\end{aligned}
$$

Analisis faktor strategis difokuskan pada kondisi yang ada dan kecenderungan yang muncul dari luar, tetapi dapat memberi pengaruh perkembangan pada wisata. Setelah mengetahui faktor-faktor strategi

$$
\begin{aligned}
& \text { Ukuran Rating } \\
& 1=\text { Sedikit kuat/lemah } \\
& 2=\text { Cukup kuat/lemah } \\
& 3=\text { Kuat/lemah } \\
& 4=\text { Sangat kuat/lemah }
\end{aligned}
$$

eksternal (External Strategic Factors Analysis Summaryl EFAS). Faktor-faktor strategis eksternal (External Strategic Factors Analysis Summary/ EFAS) nampak pada Tabel 4.4

Tabel 4.4 Faktor-faktor strategis eksternal (External Strategic Factors Analysis Summary/ EFAS) 
1. Keberadaan obyek wisata Desa Adat Osing Kemiren berdampak kepada usaha yang dikelola oleh masyarakat sekitar.

2. Keberadaan obyek wisata Desa Adat Osing Kemiren memperkenalkan budaya Khas Banyuwangi kepada wisatawan.

3. Adanya kerja sama antara perusahaan, pemerintah dan masyarakat sekitar dalam mengembangkan obyek wisata Desa Adat Osing Kemiren demi tercapainya pengembangan desa yang maksimal.

4. Tingginya perhatian pemerintah untuk pengembangan kawasan wisata Desa Adat Osing Kemiren.

5. Adanya obyek wisata Desa Adat Osing Kemiren membantu masyarakat sekitar untuk membuka lapangan pekerjaan.

$\begin{array}{lll}0,1 & 3,1 & 0,32 \\ 0,1 & 3 & 0,3\end{array}$

$0,1 \quad 3,1 \quad 0,32$

6. Adanya obyek wisata Desa Adat Osing Kemiren membantu meningkatkan pendapatan masyarakat sekitar.

7. Informasi mengenai obyek wisata Desa Adat Osing Kemiren dapat dengan mudah diakses melalui internet.

8. Ketersediaan informasi mengenai obyek wisata Desa Adat Osing Kemiren dapat dengan mudah, cepat dan tepat untuk didapatkan.

$\begin{array}{ccc}0,1 & 3,2 & 0,33 \\ 0,1 & 3,2 & 0,33 \\ 0,1 & 3,3 & 0,35 \\ 0,12 & 3,4 & 0,39 \\ 0,12 & 3,5 & 0,41 \\ & & \\ 0,82 & & 2,75\end{array}$

\section{Ancaman}

1. Adanya obyek wisata lain yang menawarkan produk wisata yang sama dengan obyek wisata Desa Adat Osing Kemiren.

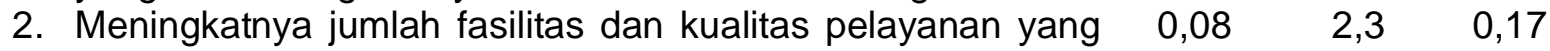
dimiliki obyek wisata pesaing.

\begin{tabular}{lcc}
\hline Jumlah & 0,16 & 0,38 \\
\hline Jumlah bobot & $\mathbf{1 , 0}$
\end{tabular}

Ukuran Bobot

0,00 : Tidak penting

0,05 : Sedikit penting

0,10 : Cukup penting

0,15 : Penting

0,20 : Sangat penting
Ukuran Rating

1 = Sedikit kuat/lemah

2 = Cukup kuat/lemah

$3=$ Kuat/lemah

4 = Sangat kuat/lemah

Tabel 4.5 Hasil Perhitungan SWOT

\begin{tabular}{clcc}
\hline No & \multicolumn{1}{c}{ Faktor-faktor } & Nilai & Total \\
\hline 1 & Faktor internal & & \\
& Kekuatan & 2,75 & 3,12 \\
& Kelemahan & 0,37 & \\
2 & Faktor eksternal & & \\
& Peluang & 2,75 & 3,13 \\
& Ancaman & 0,38 & \\
\hline
\end{tabular}


p-ISSN : 2599-1418

e-ISSN : 2599-1426

Dari perhitungan yang telah dilakukan, total nilai yang didapat dari masing-masing analisis SWOT. Kemudian untuk mendapatkan kedudukan wisata dalam matriks akan digunakan rumus sebagai berikut.

$$
\begin{aligned}
\text { Sumbu X } & =S-W \\
& =2,75-0,37
\end{aligned}
$$

Gambar 4.2 Diagram SWOT

Kuadran 3

Trun around

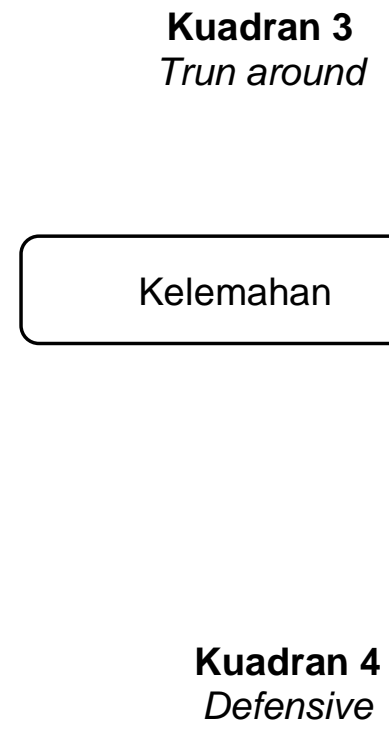

Kuadran 4

Defensive

Analisis matrik SWOT dapat menggambarkan bagaimana peluang dan ancaman dari lingkungan eksternal perusahaan diantisipasi dengan kekuatan dan kelemahan yang dimilikinya. Matrik SWOT digunakan untuk mengembangkan empat tipe alternatif strategi yaitu SO
Jurnal Pendidikan Ekonomi Undiksha

Vol. 13 No. 2 (2021)

$$
=2,38
$$

Jadi posisi wisata berada pada titik koordinat

di $(2,38: 2,37)$.

\begin{tabular}{|c|c|c|}
\hline $\begin{array}{l}\text { Faktor-faktor } \\
\text { internal (IFAS) }\end{array}$ & $\begin{array}{l}\text { Strength/Kekuatan } \\
\text { (S) } \\
>\text { Panorama masih asri. } \\
\text { menarik. } \\
\text { mevent-event } \\
>\text { Kebersihan terjaga. } \\
>\text { Kondisi jalan baik. } \\
>\text { Tersedianya listrik dan } \\
\text { jaringan telfon yang } \\
\text { memadai. } \\
>\text { Tersedianya sarana dan } \\
\text { prasarana yang menarik. }\end{array}$ & \begin{tabular}{ll}
\multicolumn{2}{l}{ Weakness/Kelemahan } \\
\\
$\begin{array}{l}\text { (W) } \\
\text { Kurang tersedianya air } \\
\text { bersih/toilet. }\end{array}$ \\
$\begin{array}{l}\text { Kurangnya } \\
\text { keamanan }\end{array}$ \\
$\begin{array}{l}\text { pengawasan } \\
\text { Kualitas SDM dan } \\
\text { rendah }\end{array}$
\end{tabular} \\
\hline
\end{tabular}

$$
\begin{aligned}
& =\mathrm{O}-\mathrm{T} \\
& =2,75-0,38 \\
& =2,37
\end{aligned}
$$

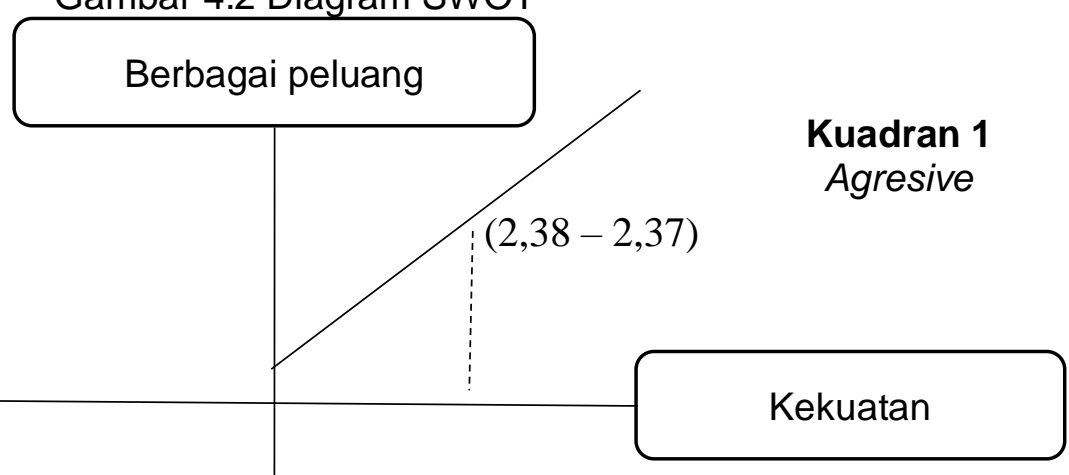

Gambar 4.3 Matrik SWOT 


\begin{tabular}{|c|c|c|}
\hline Faktor-faktor eksternal & $\begin{array}{l}\text { Masyarakat yang ramah } \\
\text { terhadap wisatawan. }\end{array}$ & \\
\hline 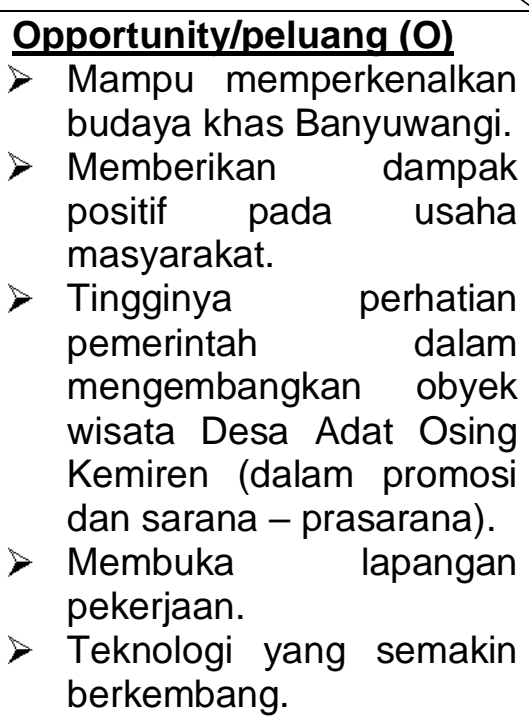 & $\begin{array}{l}\text { Strategi S-O } \\
\text { Mengoptimalkan potensi } \\
\text { yang dimiliki obyek } \\
\text { wisata. } \\
\text { Mempertahankan event- } \\
\text { event budaya yang } \\
\text { menarik. } \\
>\text { Mempertahankan } \\
\text { keramahtamahan } \\
\text { masyarakat terhadap } \\
\text { wisatawan. } \\
>\text { Melakukan promosi. } \\
\text { Adanya penganggaran } \\
\text { terhadap dana untuk } \\
\text { renovasi bangunan rumah } \\
\text { adat. }\end{array}$ & 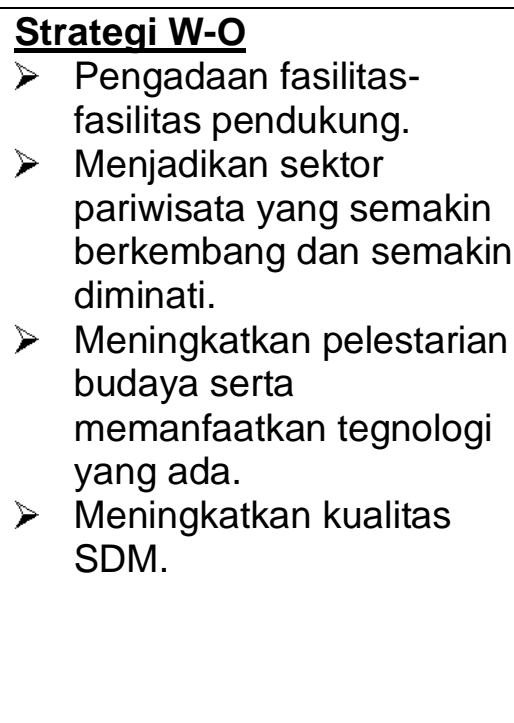 \\
\hline $\begin{array}{l}\text { Threat/Ancaman }(\mathbf{T}) \\
\text { adanya obyek wisata lain } \\
\text { yang menawarkan produk } \\
\text { wisata yang sama. } \\
\text { meningkatnya jumlah } \\
\text { fasilitas dan kualitas } \\
\text { pelayanan yang dimiliki } \\
\text { obyek wisata pesaing, } \\
\text { seperti tersedianya } \\
\text { fasilitas toko souvenir khas } \\
\text { sedangkan obyek wisata } \\
\text { Desa Adat Osing Kemiren } \\
\text { tidak menyediakannya. }\end{array}$ & $\begin{array}{l}\text { Strategi S-T } \\
\text { Menjaga kebersihan } \\
\text { obyek wisata. } \\
\text { Meningkatkan promosi. } \\
\text { Mempertahankan ciri } \\
\text { khas budaya obyek } \\
\text { wisata, seperti pagelaran } \\
\text { wisata. } \\
\text { Mengikuti perkembangan } \\
\text { untuk meningkatkan } \\
\text { persaingan dalam wisata. }\end{array}$ & $\begin{array}{l}\text { Strategi W-T } \\
\text { Pembaharuan fasilitas. } \\
\text { Meningkatkan fasilitas- } \\
\text { fasilitas pendukung khas } \\
\text { obyek wisata. } \\
\text { Meningkatkan kualitas } \\
\text { SDM, promosi dan } \\
\text { keamanan. } \\
\text { Melakukan promosi. }\end{array}$ \\
\hline
\end{tabular}

Berdasarkan uraian yang telah dipaparkan, hasil penelitian ini menunjukkan bahwa kekuatan (strength) yang dimiliki daerah tujuan wisata Desa Adat Osing Kemiren, antara lain mempunyai potensi panorama desa yang masih asri, tersedianya berbagai event-event yang unik dan menarik, kebersihan yang masih terjaga, tersedianya sarana dan prasarana yang baik dan keramahan masyarakat sekitar. Dalam hal ini, destinasi daerah tujuan wisata Desa Adat Osing Kemiren selalu mengupayakan menjaga dan mengembangkan potensi yang dimiliki agar mampu memenuhi dan memberikan kepuasan terhadap setiap pengunjung dan juga mampu bersaing dengan pesaing wisata lainnya. Selain itu terdapat kelemahan yang dimiliki oleh destinasi tujuan wisata Desa Adat Osing Kemiren, antara lain, kurang tersedianya air bersih dalam toilet, kurangnya sistem keamanan 
dan pengawasan bagi wisatawan seperti kurangnya tempat parkir dan masyarakat yang kurang berwawasan dalam hal pariwisata sehingga kurang dapat memberikan informasi yang jelas jika wisatawan membutuhkan informasi. Dari beberapa kelemahan yang dimiliki dentinasi daerah tujuan wisata Desa Adat Osing Kemiren membuat kurang efektif dalam mendatangkan pengunjung.

Adapun peluang yang dimiliki destinasi daerah tujuan wisata Desa Adat Osing Kemiren, antara lain, obyek wisata Desa Adat Osing Kemiren mampu memperkenalkan budaya khas Banyuwangi terhadap wisatawan, memberikan dampak positif pada usaha masyarakat, tingginya perhatian pemerintah dalam mengembangkan obyek wisata Desa Adat Osing Kemiren (dalam promosi dan sarana - prasarana), membuka lapangan pekerjaan dan teknologi yang semakin berkembang. Dengan beberapa peluang tersebut destinasi daerah tujuan wisata Desa Adat Osing Kemiren dapat mencapai apa yang menjadi tujuan jika peluang yang ada bisa dimanfaatkan dengan baik.

Namun semua itu tidak menutup kemungkinan terdapat ancaman yaitu adanya obyek wisata lain yang menawarkan produk wisata yang sama dan meningkatnya jumlah fasilitas dan kualitas pelayanan yang dimiliki obyek wisata pesaing, seperti tersedianya fasilitas toko souvenir khas sedangkan obyek wisata Desa Adat Osing Kemiren tidak menyediakan hal tersebut. Dengan adanya ancaman tersebut daerah tujuan wisata Desa Adat Osing Kemiren akan mendapat hambatan dalam mengembangkan wisata sekaligur mengganggu tercapainya tujuan yang diinginkan. Berdasarkan hal tersebut perlu adanya strategi yang perlu diterapkan karena pada titik potong $(2,38: 2,37)$ berada pada diagram I , dimana kondisi tersebut dapat dilakukan dengan memanfaatkan kekuatan dan peluang agar dapat meningkatkan pertumbuhan daerah tujuan wisata Desa Adat Osing Kemiren. Dengan memanfaatkan kekuatan yang dimiliki mengoptimalkan panorama desa yang masih asri, tersedianya berbagai eventevent yang unik dan menarik, kebersihan yang masih terjaga, tersedianya sarana dan prasarana yang baik dan keramahan masyarakat sekitar. Sehingga strategi yang dapat diterapkan dalam kondisi ini adalah mendukung kebijakan (growth oriented strategy).

Hasil penelitian ini sesuai dengan teori yang dikemukakan oleh Wijayati, 2019 yang menyatakan bahwa, kuadran I memberikan gambaran bahwa suatu perusahaan memiliki peluang serta kekuatan untuk dapat memandatkan peluang pasar yang ada.

\section{SIMPULAN DAN SARAN}

Berdasarkan hasil penelitian dan pembahasan analisis SWOT obyek wisata Desa Adat Osing Kemiren sebelumnya, maka dapat disimpulkan bahwa :

Kekuatan (Strenght) yang dimiliki obyek wisata Desa Adat Osing Kemiren antara lain yaitu mempunyai potensi panorama desa yang masih asri, tersedianya berbagai event-event yang unik dan menarik, kebersihan yang masih terjaga, tersedianya sarana dan prasarana yang baik dan keramahan masyarakat sekitar terhadap wisatawan. Selain itu terdapat Kelemahan (Weaknness) yaitu kurang tersedianya air bersih dalam toilet, kurangnya sistem keamanan dan pengawasan bagi wisatawan. Adapun Peluang (Opportunity) yang dimiliki obyek wisata Desa Adat Osing Kemiren yaitu mampu memperkenalkan budaya khas Banyuwangi terhadap wisatawan, memberikan dampak positif pada usaha masyarakat, tingginya perhatian pemerintah dalam mengembangkan obyek wisata Desa Adat Osing Kemiren (dalam promosi dan sarana - prasarana), membuka lapangan pekerjaan dan teknologi yang semakin berkembang.

Namun semua itu tidak menutup kemungknan terdapat Ancaman (Threat) yang dimiliki obyek wisata Desa Adat Osing Kemiren antara lain yaitu adanya obyek wisata lain yang menawarkan produk wisata yang sama dan meningkatnya jumlah fasilitas dan kualitas pelayanan yang dimiliki obyek wisata pesaing, seperti tersedianya fasilitas toko souvenir khas sedangkan obyek wisata Desa Adat Osing Kemiren 
tidak menyediakan hal tersebut. Berdasarkan dari hasil penelitian di atas menunjukkan bahwa titik potong (2,38 : 2,37 ) berada pada diagram I, dimana situasi tersebut dapat dilakukan dengan memanfaatkan kekuatan dan peluang agar dapat meningkatkan pertumbuhan obyek wisata Desa Adat Osing Kemiren. Sehingga strategi yang dapat diterapkan dalam kondisi ini adalah mendukung kebijakan (growth oriented strategy).

Dari simpulan di atas, beberapa saran yang dapat diberikan penulis adalah sebagai berikut :

1) Untuk meningkatkan atau mengoptimalkan obyek wisata Desa Adat Osing Kemiren, pihak pengelola perlu untuk melakukan perbaikan dan pengembangan pada tingkat keamanan dan pengawasan, sarana dan prasarana seperti toilet, dan pengadaan toko souvenir khas desa adat, hal tersebut akan berdampak pada tingginya minat wisatawan untuk berkunjung ke obyek wisata Desa Adat Osing Kemiren. Sehingga obyek wisata Desa Adat Osing Kemiren dapat bersaing dengan pesaing wisata lainnya.

2) Pemerintah di harapkan dapat membantu memberikan pelatihan-pelatihan terkait dengan kepariwisataan kepada masyarakat lokal agar masyarakat lokal dapat memahami dengan baik serta dapat ikut berkontribusi dalam kegiatan pariwisata.

3) Masyarakat lokal hendaknya dapat ikut berkontribusi dalam pengembangan pariwisata di Desa Adat Osing Kemiren seperti, memberikan ide atau gagasan, memberikan kritik dan saran, serta ikut berpartisipasi dalam kegiatan pariwisata yang dalam pengembangannya nanti dapat memberikan manfaat yang positif bagi kesejahteraan perekonomian masyarakat desa.

\section{DAFTAR PUSTAKA}

Arsip Dinas Kebudayaan dan Pariwisata Kabupaten Banyuwangi. (2019). Data Kunjungan Wisatawan yang datang Ke Kabupaten Banyuwangi tahun 20132019. Banyuwangi.

Nupus, T. T. (2019). Analisis Pengembangan Desa Wisata Melalui Kearifan Lokal Guna Meningkatkan Pendapatan Masyarakat dalam Perspektif Ekonomi Islam (Studi di Desa Kunjir Kecamatan Rajabasa Kabupaten Lampung Selatan). Universitas Islam Negeri Raden Intan Lampung.

Rosida, F. (2018). Pengaruh Harga dan Fasilitas terhadap Kunjungan Wisata di Pantai Air Bangis Kabupaten Pesaman Barat. Universitas Islam Negeri Sumatra Utara Medan.

Sarbini, M. B. (2018). Filsafat Pariwisata. Yogyakarta:Pustaka Pelajar.

Sugiyono. (2017). Metode Penelitian: Kuantitatif, Kualitatif dan $R \& D$. Bandung:Penerbit Alfabeta.

Tomas, M. I. A. (2017). Upaya Pengembangan Desa Wisata melalui Kelompok Sadar Wisata (Studi Desa Kupuk Kecamatan Bungkal Kabupaten Ponorogo). Jurnal Administrasi Publik, 5(5).

Wijayati, H. (2019). Panduan Analisis SWOT Untuk Kesuksesan Bisnis. Yogyakarta:Quadrant. 